\title{
ВИЗНАЧЕННЯ НАПРЯМУ РУХУ ОБ’ЄКТІВ НА ПОВЕРХНІ ВОДОЙМ
}

Determining the direction of movement of objects on the surface of water

\author{
Шпинковська M.I. ${ }^{1}$ (Shpynkovska M.I.) \\ ${ }^{1}$ Одеський національний політехнічний університет, м. Одеса
}

\section{Анотація}

Розлянуто програму визначення водних маршрутів на основі знімків поверхні Землі. Програма для розпізнавання знімків поверхні Землі використовус методи кольорової сегментації. Для визначення маршрутів використовується алгоритм пошуку шляху $\mathrm{A}$. Дана програма може бути інтегрована до систем навігації плаваючих засобів для виконання функції автоматизації визначення маршрутів по водним поверхням.

\section{Annotation}

Considered a program determining water routes based on images of the Earth 's surface. Program to recognize images of the Earth 's surface using color segmentation methods. To determine the routes used path search algorithm $A *$. This program can be integrated into the navigation systems of floating means to perform automation functions determining routes over the water.

Ключові слова

Поверхня води, кольорова сегментація, алгоритм пошуку шляху.

Системи різноманітної навігації у наш час є вже невід’ємною складовою будь-якого транспортного засобу. До таких систем відносяться крім глобальних GPS, Глонасс також і локальні, що допомагають у прокладанні оптимального маршрута між двома пунктами на поверхні Землі. Наприклад, Google maps містить набір додатків, побудованих на основі безкоштовного картографічного сервісу і технологій, які надає компанія Google, i які вельми корисні під час пересування по невідомих ділянках земної поверхні. Актуальність розвитку систем визначення напряму руху по водній поверхні зумовлена збільшенням кількості водного транспорту та інших об’єктів що рухаються у водному середовищі, а також ускладненням задач, які мають бути при цьому виконані. Це вигідно $з$ економічної точки зору, системи навігації можуть прокласти оптимальний шлях по найкоротшій можливій траєкторії, що дозволить економити на пальному. Також такі системи зменшують вірогідність непередбачуваних випадків, зменшуючи до мінімуму вплив людського фактору у керуванні. Існуючі системи навігації на водній поверхні з використанням глобальних систем позиціонування $є$ вельми складними і коштовними. Пропонується система визначення прибережних водних маршрутів для будь яких плаваючих об’єктів за допомогою фотознімків із космосу без застосування спеціального обладнання. Розглянемо деякі 3 типових програмних пакетів навігації, які можна використати для визначення напряму руху.

По-перше, це карти Google (Google Maps; раніше Google Local) - набір додатків, побудованих на основі безкоштовного картографічного сервісу і технології, що надаються компанією Google [1].

Сервіс являє собою карту та супутникові знімки (рис. 1) планети Земля (а також місяця і Марса). 3 сервісом інтегрований бізнес-довідник і карта автомобільних доріг, з пошуком маршрутів, що охоплює США, Канаду, Японію, Росію, Гонконг, Китай, Великобританію, Ірландію (центри міст) і деякі райони Європи. 


\section{АВТОМАТИЧНІ І АВТОМАТИЗОВАНІ СИСТЕМИ УПРАВЛІННЯ ТЕХНОЛОГІЧНИМИ ПРОЦЕСАМИ}

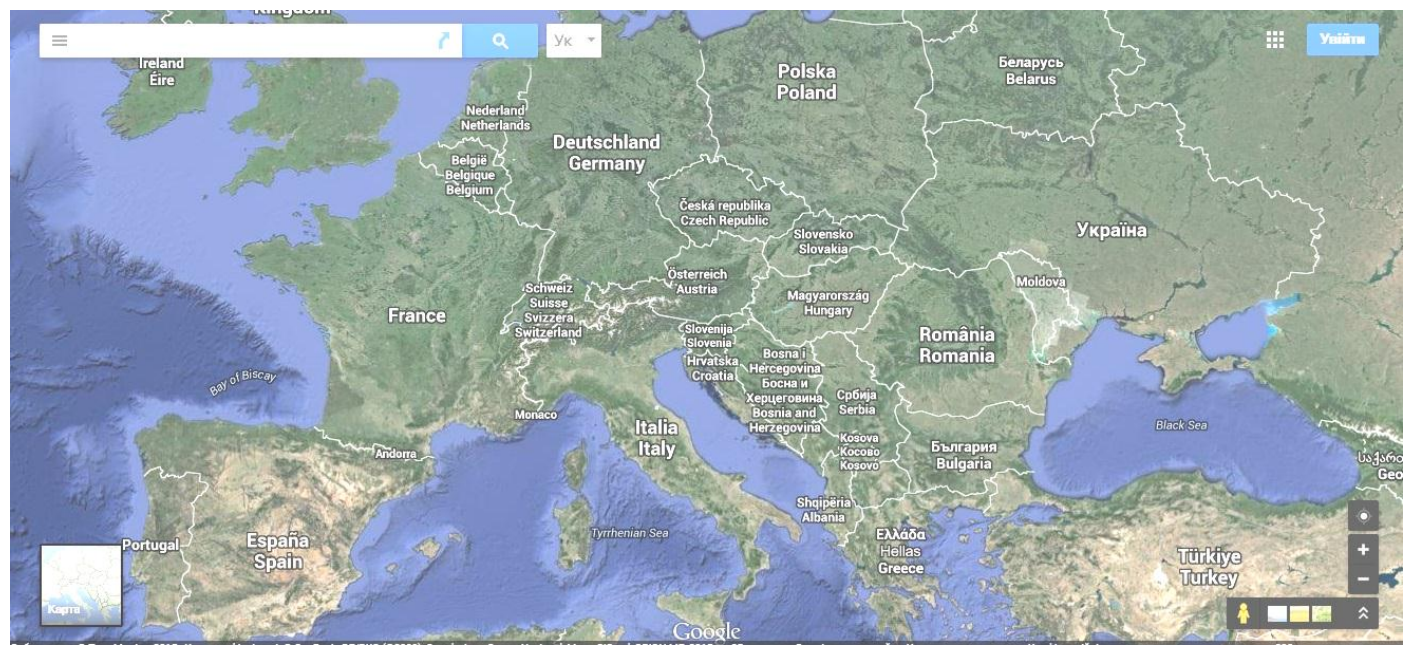

Рис. 1. Супутниковий знімок Європи у сервісі Google Maps

По-друге, також досить популярним є програмний продукт OpenStreetMap (OSM) - некомерційний вебкартографічний проект по створенню силами співтовариства учасників-користувачів Інтернету детальної вільної і безкоштовної географічної карти світу [2].

Для створення карт використовуються дані з персональних GPS-трекерів, аерофотографія, відеозаписи, супутникові знімки і панорами вулиць, надані деякими компаніями, і просто знання людини, що малює карту. Використання цих сервісів, подібних Google Maps, без дозволу правовласника неможливо. У OpenStreetMap для створення карти використовується принцип Вікі. Кожен зареєстрований користувач може вносити зміни до карти.

Готові для використання карти доступні онлайн на самому сайті OpenStreetMap і через безліч інших сайтів (що мають додаткові функції). За допомогою функції "Експорт" можна отримати HTML код для вставки на будьякий сайт 3 можливістю нанесення маркера (але є і потужніші інструменти, такі як Еаsутар, за допомогою яких, наприклад, можна будувати маршрути). Карти також доступні для скачування в початковому форматі і у форматах для різних автомобільних і інших навігаторів.

В третє, також відома програма розробників компанії NNG з Угорщини - iGO. На ринку доступні версії під Windows, Windows Mobile, Apple iOS, Android [3]. Для програм iGO доступні карти більше 70 країн світу. За наявності карт декількох країн будь-яка версія програми забезпечує скрізну навігацію через державні кордони, без перемикання карт вручну. Основними постачальниками картографічного матеріалу для програм iGO є компанії Navteq i Teleatlas, окрім цього, карти багатьох країн отримуються у локальних розробників (карти країн Східної Європи). Постачальником карти України є компанія "Карт Бланш Україна". Користувачі ліцензійних програм iGO можуть придбати додаткові карти і відновити їх через офіційний портал компанії NNG.

Google Maps $\epsilon$ найбільш глобальною системою навігації. У розпорядженні користувачів точна копія земної поверхні, створена з мозаїки супутникових знімків та карти. Ви маєте можливість проглядати територію будь якої країни, вивчати іiі географію та розташування iii головних магістралей. Прокладання маршруту потрібного користувачеві у Google Maps не обмежується територією однієї країни, більш того прокладання маршруту задається у режимі «від точки до точки», тобто ми задаємо повну адресу від точки старту до точки призначення і Google Maps прокладає потрібний нам маршрут. Під час прокладання можливо вибрати спосіб пересування і якщо це буде піший спосіб на велику відстань, то буде змодельований найбільш облегшена подорож за допомогою усіх видів громадського транспорту, який є у базі. Величезним плюсом є й те, що Google Maps повністю безкоштовний сервіс і доступ до нього можливо отримати маючи підключення до Інтернету.

Сервіс OpenStreetMap у більшій своїй частині схожий на Google Марs окрім відмінностей у заповненні його карт. Окрім того що тут також використовується мозаїка знімків зі супутника, детальніше його редагування виконується самими користувачами сервісу. Також прокладення шляху від однієї точки до іншої відбувається по вже відзначеним раніше маршрутам користувачів.

Автонавігаційні системи Navteq та IGO носять більше локальний характер, щоб мати змогу отримати навігаційні данні потрібно завантажувати карти місцевості. Проте, сервіс навігації тут звичайно більш докладний та досконалий. В обох цих системах використовується так звана технологія «від дверей до дверей», тобто автомашина проводиться по всьому заданому маршруту, постійно отримуючи потрібні вказівки.

Програму визначення водних маршрутів вирішено зробити з використанням безкоштовного cepвicy Google Maps для пошуку потрібної нам місцевості. Використовуючи Google Maps API система матиме змогу через Інтернет підключитись до сервісу Google Maps та використовувати його моделі земної кулі (водні прибережні та 
річкові ділянки). Вибравши потрібну частину земної поверхні, достатньо натиснути відповідну кнопку і ця ділянка завантажуватиметься до програми, а зображення ділянки зберігатиметься у папці з програмою.

Функціональне призначення системи - отримання зі вхідного кольорового фотознімку поверхні землі змодельованого маршруту плаваючого засобу на водній поверхні.

Основні задачі які виконує система:

1. завантаження фотознімку поверхні землі чи використання сервісу Google Maps;

2. розбиття вхідного зображення на окремі зони;

3. кольорова сегментація вхідного зображення;

4. виділення зон прохідності;

5. формування тривимірних копій вхідного зображення;

6. виділення маршрутів для плаваючих засобів.

Архітектурні атрибути системи виглядатимуть наступним чином [4-5]:

1. Організація шарів програми. Цей атрибут визначає стратегію, за якою відбувається поділ програми на шари. Компоненти програми розшаровані за моделлю MVC. Така модель дозволяє відокремити дані що оброблюються від їх представлення кінцевому споживачеві та основну логіку роботи додатку. Організація шарів програми наведена на рисунку 2.

Шар під назвою View фактично представляє інтерфейс користувача і являє собою головну форму програми 3 iï елементами управління.

У шарі Model розташовані компоненти, що є представленням даних або інструментом, що їх обробляє. Компонента Image є контейнером для розміщення зображення та супутніх даних, які обробляються. Компонента ImageOperations створена для виконання різноманітних перетворень зображень та отримання даних 3 них. У компоненті Segmentation реалізовано методи кластерізації зображень.

2. Відображення ключового сценарію. Для його візуалізації побудовано UML діаграму послідовностей, яку представлено на рисунку 3.

3. Організація доступу до даних. Дані уявляють собою файли на комп’ютері користувача. Програма має можливість читати та записувати файли на файлову систему комп’ютера, на якому вона виконується;

4. Управління винятковими ситуаціями. Інтерфейс програми розроблено таким чином, щоб дії користувача не могли призвести до неоднозначних ситуацій. При завантаженні зіпсованого зображення виводиться попередження, що дане зображення не може бути завантаженим. При спробі прокладення шляху по не обробленому зображенню виводиться попередження, що зображення ще не оброблене. При натисканні на ділянки які система розпізнала як «суша» чи «недостатня глибина», виводиться попередження що дана місцевість являється сушею чи недостатньо глибока для прокладення маршруту. Якщо під час прокладення маршруту ви вибрали кінцевою точкою водну поверхню, але прокладення маршруту неможливе, то з'являється також спеціальне попередження. Неможливо використати кнопки «Корабль» та «Распознавание», не завантаживши попередньо вхідне зображення (кнопки тимчасово заблоковано).

5. Логування програмному додатку не передбачено за відсутністю потреби аналізу послідовності дій користувача.

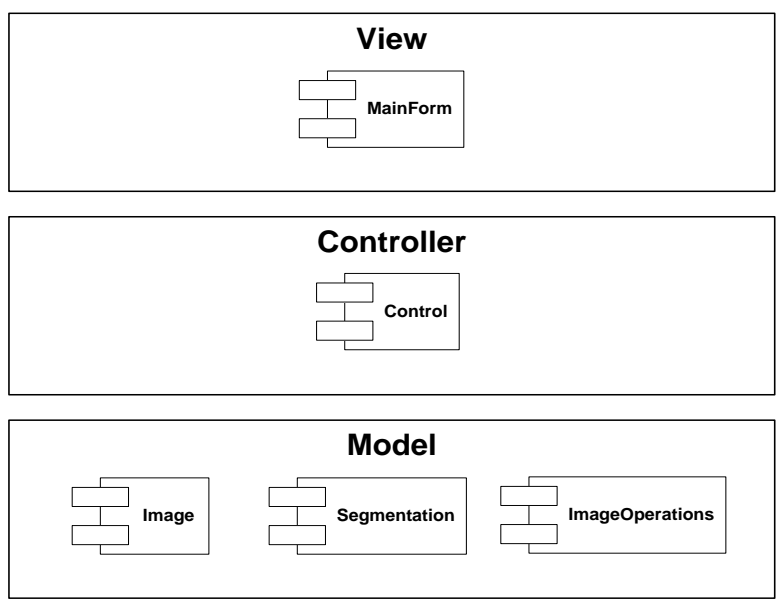

Рис. 2. Організація шарів програми 


\section{АВТОМАТИЧНІ І АВТОМАТИЗОВАНІ СИСТЕМИ УПРАВЛІННЯ ТЕХНОЛОГІЧНИМИ ПРОЦЕСАМИ}

6. Валідація даних. Усі поля, що призначені для введення даних користувачем, захищені від спроб ввести у них некоректні дані. Вхідне зображення не має бути розміром, меншим ніж 600 х 600 пікселів. Зіпсоване зображення не завантажується.

7. Атрибути користувача. Передбачено наявність інструкції та технічної документації.

При завантаженні зображення користувач вказує його розташування на дисковому просторі свого комп'ютера. Зображення завантажується та відображається користувачеві у початковому вигляді, без будь-якої обробки. У процесі роботи програми воно буде змінюватись і для економії місця на диску буде зберігатись лише його адреса розміщення, а при необхідності завантажуватись повторно, що дасть змогу зменшити потреби програмного додатку в оперативній пам'яті.

На етапі сегментації вирішується задача розділення кольорів вхідного зображення на групи. У кожній групі містяться близькі за відтінком кольори. Задача розділення об'єктів на групи за принципом «схожі об'єкти входять до однієї групи», вирішується алгоритмами кластеризації. Кластеризація проводиться по трьом ознакам компонентам кольорів. У результаті кластеризації кожен колір, що присутній на вхідному зображенні, повинен належати одному із кластерів [6-7].

Отже, алгоритм кластеризації на вході отримує невпорядкований набір об'єктів, а в результаті повертає той самий набір, де кожен об'єкт має приналежність до певної групи.

При програмній реалізації системи за основу алгоритма кольорової сегментації обраний алгоритм «kсередніх», так як саме він є одним із найпопулярніших, продуктивних і досить просто реалізується програмно. Його робота заключається у пошуку точок із схожим кольором та приведення їх до спільного відтінку.

Після кольорової сегментації розв'язується наступна задача - виділення зон прохідності для об'єктів на водній поверхні, тобто визначення глибини у будь якій зоні вхідного зображення. Під такими зонами розуміються комірки у яких можливе прокладання маршруту, якщо задані умови виконуються. У даній системі зонами прохідності являються комірки відповідаючі за водяну поверхню, глибина якої не менша ніж мінімально можлива глибина для вибраного плаваючого засобу (що визначається на попередньому кроці). У картографії існує спеціальна шкала глибин та висот. Вона є основою для виділення прохідних зон на вхідному зображені [7].

Спочатку виділяється водяна поверхня і суша. Другим кроком створюються масиви зон прохідності i непрохідності. Використовуючи значення RGB шкали глибин, змінним (коміркам) привласнюється значення червоного, зеленого та синього каналів згідно отриманої мінімально можливої глибини. Потім циклічно порівнюється значення змінної із значенням кожної зони, визнаної водою. За виконанням логічної умови комірка заноситься у масив прохідних зон, якщо навпаки, то у масив непрохідних.

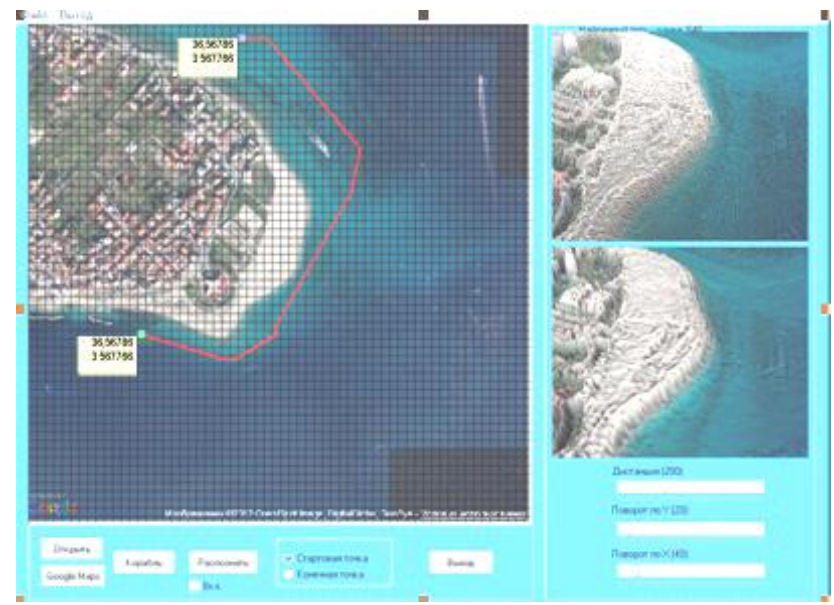

Рис. 4. Результат прокладення маршруту 
АВТОМАТИЧНІ І АВТОМАТИЗОВАНІ СИСТЕМИ УПРАВЛІННЯ ТЕХНОЛОГІЧНИМИ ПРОЦЕСАМИ

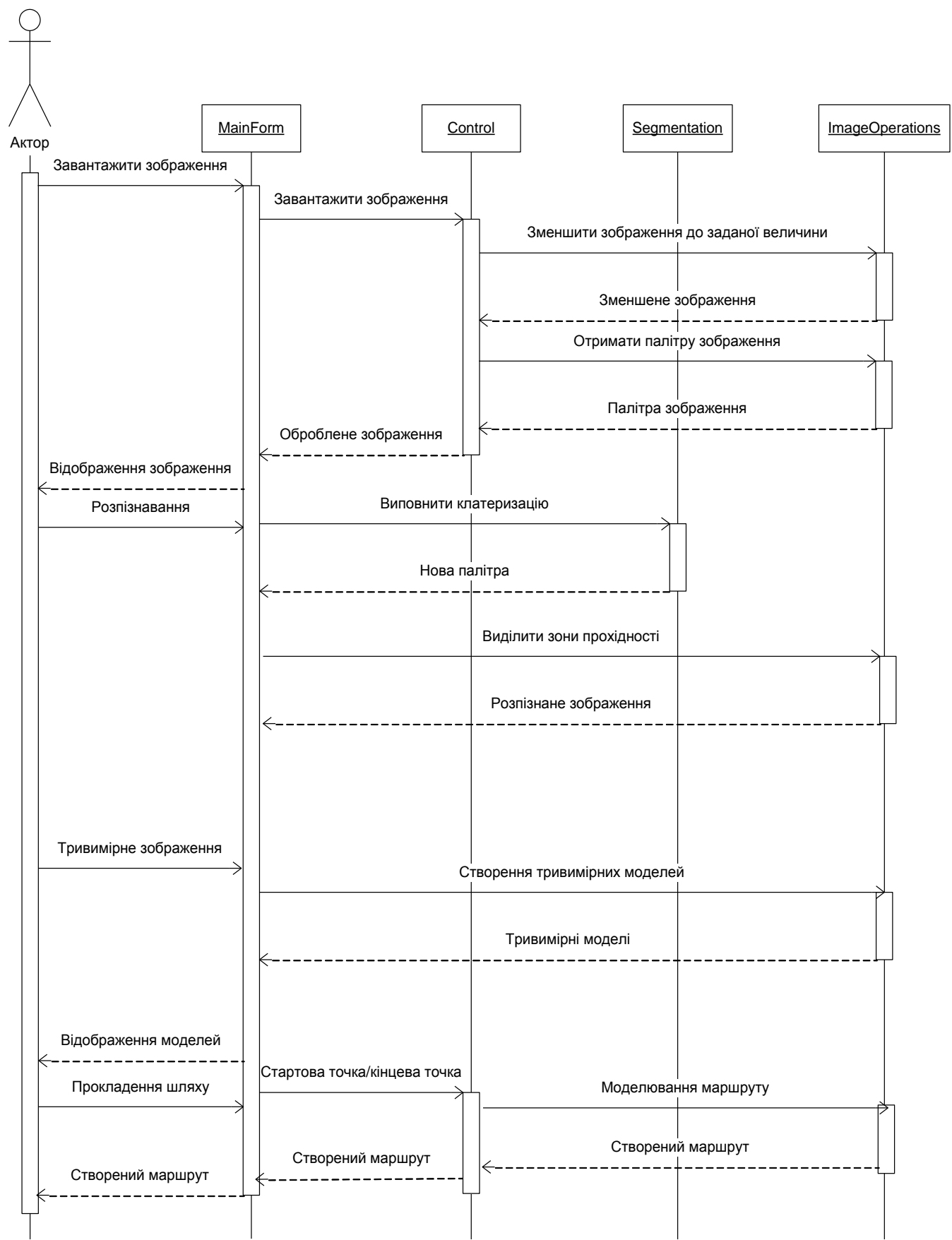

Рис. 3. Діаграма послідовностей операцій об'єктів системи

За основу алгоритму для пошуку шляху був взятий алгоритм $\mathrm{A}^{*}$ (A star), який являється найефективнішим для пошуку шляху у комірковому просторі, має високу продуктивність, а також доволі не складний для програмної реалізації [8]. Результат прокладання маршруту від початкової до кінцевої точок біля узбережжя наведено на рис. 4 у вигляді червоної лінії. 
Якщо під час вибору точок з'явилось попередження про недостатню глибину, потрібно вибрати більш глибше місце і повторити розрахунки. Основний код програми написаний мовою програмування Delphi 7.0 із залученням спеціальної бібліотеки OpenGL [9]. Підтримуються основні формати вхідного зображення: JPEG, BMP, PNG тощо. Систему можна використовувати у господарчому комплексі держави для визначення шляху руху об'єкту (плаваючих засобів різних типів і розмірів) по водній поверхні у відкритих та закритих водоймах, для визначення глибини водойм. Необхідною умовою для роботи системи є застосування актуальних на часі знімків земної поверхні.

Література

1. Google Maps [Електронний pecypc]: [Вільна інтернет-енциклопедія]. - Режим доступу: http://uk.wikipedia.org/wiki/Google_Maps (дата звернення 20.08.2015).

2. OpenStreetMap [Електронний ресурс]: [Вільна інтернет-енциклопедія]. - Режим доступу: http://uk.wikipedia.org/wiki/Google_Maps (дата звернення 20.08.2015).

3. IGO [Електронний ресурс] / Сайт розробника. - Режим доступу: http://www.igomyway.com/

4. Ту Дж. Принципы распознавания образов / Дж. Ту, Р. Гонсалес; под ред. Ю. И. Журавлева; пер. с англ. И.Б. Гуревича. М.: Мир. - 1978. - 413с

5. Николенко С. Алгоритмы кластеризации. Машинное обучение / С. Николенко. - М.: Мир. - 2006. - 239 с.

6. Котов А.М. Кластеризация данных: Алгоритмы кластерного анализа / А.М. Котов, Н.И. Красильников. М.: Мир. - 2006. - 527 с.

7. Техническое зрение в системах управления мобильными обьектами - 2010: Труды научно-технической концеренции-семинара. Вып. 4 / Под ред. М.М. Назирова. - М.:КДУ, 2011. - 328c.

8. A* search algorithm [Електронний pecypc]: [Вільна інтернет-енциклопедія]. - Режим доступу: https://en.wikipedia.org/wiki/A*_search_algorithm (дата звернення 20.08.2015).

9. Хомоненко А. Delphi 7. Наиболее полное руководство/ А. Хоменко, В. Гофман, Е. Мещеряков, В. Никифоров.: ВНV - Санкт - Петербург - 2006. - 413 с.

References

1. Google Maps [Elektronniy resurs]: [VIlna Internet-entsiklopedIya].-Rezhim dostupu: http://uk.wikipedia.org/wiki/Google_Maps (data zvernennya 20.08.2015).

2. OpenStreetMap [Elektronniy resurs]: [VIlna Internet-entsiklopedIya].-Rezhim dostupu: http://uk.wikipedia.org/wiki/Google_Maps (data zvernennya 20.08.2015).

3. IGO [Elektronniy resurs] / Sayt rozrobnika. - Rezhim dostupu: http://www.igomyway.com/

4. Tu Dzh. Printsipyi raspoznavaniya obrazov / Dzh. Tu, R. Gonsales; pod red. Yu. I. Zhuravleva; per. s angl. I.B. Gurevicha. M.: Mir. - 1978. - 413s

5. Nikolenko S. Algoritmyi klasterizatsii. Mashinnoe obuchenie / S. Nikolenko. - M.: Mir. - 2006. - 239 s.

6. Kotov A.M. Klasterizatsiya dannyih: Algoritmyi klasternogo analiza / A.M. Kotov, N.I. Krasilnikov. - M.: Mir. 2006. $-527 \mathrm{~s}$.

7. Tehnicheskoe zrenie $\mathrm{v}$ sistemah upravleniya mobilnyimi obektami - 2010: Trudyi nauchno-tehnicheskoy kontserentsii-seminara. Vyip. 4 / Pod red. M.M. Nazirova. - M.:KDU, 2011. - 328s.

8. A* search algorithm [Elektronniy resurs]: [VIlna Internet-entsiklopedIya]. - Rezhim dostupu: https://en.wikipedia.org/wiki/A*_search_algorithm (data zvernennya 20.08.2015).

9. Homonenko A. Delphi 7. Naibolee polnoe rukovodstvo/ A. Homenko, V. Gofman, E. Mescheryakov, V. Nikiforov.: BHV - Sankt - Peterburg - 2006. - 413 c. 